\title{
O SISTEMA ALEXANDRINO E O SISTEMA EPICURISTA NA FILOSOFIA DA HISTÓRIA DO JOVEM MARX
}

\author{
Júlia Lemos Vieira*
}

RESUMO: Nos Cadernos preparatórios de sua Tese de Doutorado intitulada Diferença entre as filosofias de Demócrito e Epicuro, esboçados em 1839, Marx se contrapôs a um conteúdo teológico em Hegel através de uma crítica à tendência tradicional da filosofia em teologizar-se dada numa revisão do ocaso da filosofia grega em dois sistemas opostos. O primeiro teria sido o misticismo da filosofia alexandrina; o segundo, o atomismo epicurista que desenvolveu uma dialética peculiar. Sugerindo uma filosofia da história alternativa à de Hegel, Marx pretendia indicar que a democracia não sofreu ocaso na Grécia por conta do desenvolvimento da razão genuinamente filosófica, e sim por conta da vitória da razão filosófica tergiversada em teologia. Era preciso, neste sentido, resgatar a filosofia do sistema epicurista.

PALAVRAS-CHAVE: Filosofia; democracia; Antiguidade; Marx; Hegel.
* Doutora em

Filosofia pela

Universidade de São

Paulo.

Universidade Federal de Goiás.

lemos.julia@gmail. com

\begin{abstract}
In the Preparatory Notebooks of his doctoral thesis entitled Difference between the Philosophies of Democritus and Epicurus, outlined in 1839, Marx countered a theological content in Hegel via a critique of the traditional trend of philosophy in theologize given in a review of the decline of Greek philosophy into two opposing systems. The first would have been the mysticism of the Alexandrian philosophy and the second would have been the Epicurean atomism who developed a peculiar dialectic. Suggesting an alternative to the philosophy of history in Hegel, Marx wanted to indicate that democracy has not suffered decline in Greece due to the development of the genuinely philosophical reason but because of the victory of the lost of philosophical reason in theology. It was necessary, in this sense, rescue the system of Epicurean philosophy.
\end{abstract}

KEYWORDS: Philosophy; Democracy; Antiquity; Marx, Hegel. 
M arx considerou que a queda da filosofia num obscurantismo idealista ocorrera desde Sócrates, mas teria tido oportunidade de saída pertinente com Epicuro. Este conseguiu se libertar dos riscos de misticismo da consciência filosofante através de seu atomismo. Em contraposição, Hegel teria se mantido na razão alexandrina, feito o voo da razão numa compreensão insuficiente dos riscos dos seus pressupostos. Assim, embora concordasse com Hegel que a filosofia moderna desenvolvera a razão dada na filosofia alexandrina, o jovem Marx indicara que Hegel não teria percebido que esta continha o embrião de um desvio da razão de seu empreendimento de realização da liberdade. Para Marx, na filosofia alexandrina, a razão desenvolveu o potencial de sair da dialética e transformar-se em puro idealismo, enquanto a alienação da razão na filosofia epicurista, eclética, se manteve na dialética. Ocorre que Hegel desenvolveu a filosofia alexandrina de modo inocente, não consciente de que nela a razão poderia se perder.

Em sua tese de Doutorado, Marx buscou indicar que a alienação humana é justamente essa alienação inconsciente surgida na Antiguidade grega através da distinção dos filósofos em relação aos sábios legisladores, quando passaram a buscar um bem em si, fora do consenso público democrático. O processo de alienação da razão (sábio) em relação à vida pública (povo) teria gerado o reverso da libertação do homem, o potencial da razão de não se desenvolver para uma consciência dos seus pressupostos efetivos, para uma negação de seu estado de alienação como liberdade real. Marx criticou Hegel através dos termos próprios da dialética hegeliana que ele busca encontrar de algum modo reverso em Epicuro. Tratou-se de uma crítica em termos do próprio Aufhebung hegeliano, recusando um julgamento moral deste e reelaborando uma filosofia da história a partir daquela proposta por Hegel com vistas a resgatar a dialética do seu desvio da liberdade - a qual só é possível na razão como democrática.

\section{FILOSOFIA DA HISTÓRIA EM HEGEL: UMA IRRECONCILIÁVEL OPOSIÇÃo ENTRE RAZÃo FILOSÓFICA E DEMOCRACIA}

A relação entre a filosofia e o Estado político é para Hegel um processo impulsionado pela vontade enquanto paixão particular dos homens. A razão chega a ser razão consciente passando pelo desenvolvimento da constituição do Estado racional. A paixão humana seria o impulso da determinação da razão através do desenvolvimento histórico do Estado. Em suas próprias palavras:

Dissemos que nada se realizou sem o interesse e a atividade daqueles que participaram. (...) Então devemos dizer, de maneira geral, que nada de grande acontece no mundo sem paixão. São dois momentos que intervêm em nosso objeto: o primeiro é a ideia, o segundo, as paixões humanas; um é a urdidura do tecido, o outro, a trama do grande tapete da história universal que se desenrola perante nós. $\mathrm{O}$ centro concreto de ambos é a liberdade moral no Estado (...) um Estado é bem organizado e vigoroso quando seus fins gerais se 
conjugam com os interesses particulares dos cidadãos; um encontra no outro a sua satisfação e a sua concretização - proposição em si altamente relevante. Porém, o Estado necessita de muitos eventos, invenções de organizações apropriadas (...) São necessárias também batalhas entre os interesses particulares e as paixões (...) a história consensual não começa com qualquer objetivo consensual. (Hegel, 1999 [1837], p. 28)

Hegel (1999 [1837]) considerou que a República Democrática havia sido uma forma de Estado própria apenas a um momento anterior da razão; momento de anteposição dos homens em relação ao mundo, a uma realidade de continuidade entre o particular e o público, momento de consciência infantil da Razão. E este momento teria desaparecido para sempre após o desenvolvimento do conhecimento na sociedade grega levando à própria decadência desta.

Em sua argumentação de superação da razão democrática pelo desenvolvimento da razão filosófica, Hegel indicou que o primeiro momento da razão consciente teria se dado na Grécia, mais especificamente na segunda fase de unidade grega. A filosofia grega, entretanto, teria se desenvolvido de dois modos gerais: o modo alexandrino, culminado em Sócrates e Platão, e o modo eclético, dos sistemas cínico, cético e epicurista. As duas tendências filosóficas teriam partido dos chamados Sete Sábios, os primeiros legisladores gregos, e do filósofo Anáxagoras - o qual teria sido a expressão do momento da dualidade da razão especulativa que depois se desenvolvera cindida nas tendências alexandrina e eclética.

Originada por uma "migração e mistura de tribos", por uma realidade de diversidade de costumes dotada de "estranhamento interno" (Hegel, 1999 [1837], p. 191), a primeira fase grega caracterizou-se por uma moral baseada em mitos trazidos pelos estrangeiros. A Guerra de Troia e o desenvolvimento da obra de arte ${ }^{1}$ é que, em conjunto, teriam selado a unidade subjetiva e objetiva entre os gregos. Esta unidade se expressou na racionalidade política elaborada pelos primeiros legisladores, conhecidos como sete sábios. Assim, o desenvolvimento do Estado democrático baseou-se numa identidade entre indivíduo e comunidade apreendida pelos gregos como algo praticamente natural. Os gregos simplesmente não concebiam ainda diferenciar interesse individual e interesse geral, da comunidade. Neles o interesse individual era propriamente o da comunidade, interesse universal, ou seja, a identidade indivíduo e comunidade era completa. Apenas nessa condição, na qual os costumes surgiam para os cidadãos como lei natural e inquestionável, é que o Estado democrático se dava como melhor expressão da razão:

Só uma constituição democrática poderia ser apropriada para esse espírito e esse Estado (...) o interesse da comunidade pode permanecer na vontade e na decisão dos cidadãos - e essa deve ser a base da constituição grega (...) A constituição democrática aqui é

\footnotetext{
${ }^{1}$ De acordo com Hegel, enquanto a Guerra de Troia desenvolveu um objetivo comum entre as diferentes tribos, a arte "é o espírito vivo e universal e, ao mesmo tempo, o espírito autoconsciente dos indivíduos isolados".
} 
a única possível: os cidadãos ainda não estão conscientes dos seus interesses particulares, logo, de um elemento corruptor. (Hegel, 1999 [1837], p. 211)

O Estado racional na Grécia antiga só podia ser uma democracia porque naquele momento não se tratava de uma razão especulativa desenvolvida: o que se transformava em lei não eram frutos de uma razão madura, e sim dos hábitos. O que se configurava como lei para os gregos eram seus próprios costumes, ou seja, a lei não derivava da reflexão:

Para o indivíduo, o substancial do direito, os assuntos de Estado e o interesse geral são o essencial, mas apenas como costume, sob a forma da vontade objetiva. (...) A lei existe (...) vigora pura e simplesmente por ser lei (...) existem leis nessa moralidade objetiva como uma necessidade natural. (...) Quando o costume e o hábito são a forma na qual se quer e se faz o lícito, então essa forma é fixa, pois ainda não possui o inimigo constituído pela imediatez - a reflexão e a subjetividade da vontade. (Hegel, 1999 [1837], p. 211)

Hegel considerou, então, que a democracia ali só foi possível porque a moralidade que se tornava lei era imanente e objetiva, dada pela crença nos hábitos como verdades inquestionáveis. Assim, a democracia foi própria a uma realidade específica na qual os indivíduos, ainda que racionais, eram desprovidos de uma razão que se pensa a si mesma como sujeito, desprovidos de uma razão mais consciente. É a ingenuidade da razão que ainda lhes permitia acreditar nos meros costumes como lei natural. O fato de os primeiros legisladores terem sido os sete sábios não indicaria uma rejeição a essa leitura da história:

Os primeiros legisladores são conhecidos como os Sete Sábios, o que não nos leva a concluir que eram sofistas ou mestres da sabedoria, apresentando conscientemente o lícito e o verdadeiro, mas apenas que eram pensadores cuja doutrina ainda não progredia para uma verdadeira ciência. Eram homens práticos e políticos. (...) Sólon lhes deu uma constituição estatal por meio da qual todos tiveram direitos iguais, sem, porém, chegar ao ponto de tornar a democracia abstrata. O principal momento da democracia é o caráter moral. (Hegel, 1999 [1837], p. 210)

Para Hegel, os sete sábios, primeiros legisladores, não basearam as leis em reflexões conceituais nem delas chegaram a derivar uma essência: eles teriam permanecido como meros formalizadores de costumes - práticos, ou ainda, quando inovadores em suas doutrinas, não progrediam para uma ciência desta. Vide o próprio Sólon, que não derivara da lei de direitos iguais qualquer conceito mais abstrato e universal, como, por exemplo, igualdade bumana. Os sete sábios apenas confirmaram a força do domínio dos interesses gerais e a carência completa de subjetividade dos gregos, os quais não decidiam nada por reflexão individual: mesmo em questões individuais, buscavam consultar uma subjetividade dominante, tal como 
a do oráculo e, com o progresso da democracia, a dos tribunos. ${ }^{2}$ Os sete sábios legisladores possuíam do povo uma confiança outrora depositada nos oráculos justamente por não terem ainda uma razão livre evidente. O desenvolvimento da razão livre não estaria de acordo com a democracia porque fora, na verdade, o próprio processo de ruína desta:

À democracia - como só existiu na Grécia - estão vinculados os oráculos. À decisão autônoma pertence uma subjetividade determinante da vontade, que é estabelecida por razões preponderantes; os gregos porém não possuíam essa força (...). Os gregos também seguiam em questões particulares outras fontes de consulta e não decidiam nada independentemente. Com o progresso da democracia, vemos como, nas questões mais importantes, o oráculo não era mais consultado; nesses assuntos tornaram-se válidas e decisivas as decisões dos tribunos. Assim como, na mesma época, Sócrates inspirava-se em seu demônio, os líderes populares e o povo tomavam suas próprias decisões. Com isso surgiram a ruína, a desordem e a constante alteração da constituição. (Hegel, 1999 [1837], p. 210)

O Estado democrático teria começado a decair com o surgimento de uma razão mais consciente de sua liberdade já em Anaxágoras, mas só a partir de Sócrates é que tal ocaso passara a se tornar mais grave: "o grego Anaxágoras foi o primeiro a afirmar que o voũ - a inteligência em geral ou razão - rege o mundo (...). Sócrates adotou o pensamento de Anaxágoras, que se tornou dominante na filosofia - com exceção de Epicuro, que atribuía todos os acontecimentos ao acaso" (Hegel, 1999 [1837], p. 210). Com Sócrates os gregos passam a não ter mais a confiança nos costumes como fundamento da verdade. Hegel considerou que a partir de Sócrates a razão livre teria se disseminado entre os gregos gerando uma clivagem entre a moralidade e os costumes, invalidando as leis e assim tornando impossivel a existência do Estado democrático. Apenas antes da razão livre a democracia foi possível, pois apenas numa razão inconsciente de si o hábito se identifica imediatamente com a lei.

Assim, foram os sete sábios "os primeiros a formular proposições universais, mas naquele tempo a sabedoria era colocada num ambiente de percepção concreta" (Hegel, 1999 [1837], p. 210). Na vida política e no exercício da arte, "com os sofistas teve início a reflexão sobre o existente e o raciocínio": oscilações das representações. Os sofistas, "mestres nas formulações do pensamento, (...) deixaram os gregos pasmos” (Hegel, 1999 [1837], p. 210) justamente porque sabiam manipular conceitos - dada a necessidade de os discursos apresentarem o essencial ao povo - e ensinaram aos gregos o exercício de desenvolvimento do intelecto. Entretanto, "os sofistas referiam-se apenas aos homens subjetivos" (Hegel, 1999 [1837], p. 210) e não ao homem em geral. Por outro lado:

Já Anaxágoras havia ensinado que o próprio pensamento seria a essência absoluta do mundo. Foi em Sócrates que, no início da Guerra do Peloponeso, o princípio da interioridade, da independência

\footnotetext{
${ }^{2}$ Ibid., p. 210.
} 
absoluta do pensamento em si, obteve uma livre manifestação. Ele ensinou que o homem deve se descobrir e reconhecer em si mesmo o que é justo e bom, e que isso, segundo a natureza do justo e bom, seria universal. (...) Sócrates colocou o sujeito como algo decisivo em oposição à pátria e aos costumes, pelo fato de que ele deixou ao juízo e à convicção a determinação da ação humana. (Hegel, 1999 [1837], p. 210)

Para Hegel, portanto, o princípio que Sócrates tomou do dualismo de Anaxágoras acarretou o declínio da democracia grega, começando por Atenas, chegando a Esparta, na medida em que questionou a inseparabilidade do pensamento em relação à vida real, justamente a unidade que tornava a democracia possível:

O princípio de Sócrates comprovou-se revolucionário perante o Estado de Atenas, pois a característica desse Estado é que o costume constitui sua forma, ou seja, a inseparabilidade do pensamento da vida real. (...) o que eles condenaram em Sócrates já estava bastante enraizado neles (...) Em Atenas desenvolveu-se cada vez mais esse sublime princípio, que era o próprio declínio da existência e da substância do Estado ateniense: o espírito tinha a tendência a se auto-satisfazer, a refletir. (....) Em Esparta, surge o mesmo declínio que o sujeito em si tenta impor contra a vida moral comum. (Hegel, 1999 [1837], p. 228)

O ponto de declínio do povo grego ocorreu na separação entre o real e o ideal por conta da primeira manifestação da razão livre num sentido individual, quando o sujeito se voltou contra a moral comum. Para Hegel, este ponto de declínio da democracia que é o princípio socrático seguiu no mundo ocidental através de Alexandre, o grande - discípulo de Aristóteles. Assim, "com Aquiles começa o mundo grego, (...) com Alexandre ele termina" (Hegel, 1999 [1837], p. 232).

Portanto, Hegel desenvolveu em sua filosofia da história uma oposição à democracia no mundo moderno. Defendeu que o Estado democrático não se resumia a uma constituição representativa, mas exigia uma realidade de identidade ingênua entre interesse particular e interesse geral. A mera participação por voto não seria suficiente para determinar de modo absoluto a identificação do cidadão com o interesse geral outrora possível na Grécia e "é por isso que, na Revolução Francesa, nunca a constituição republicana se concretizou como uma democracia, e a tirania, o despotismo, levantou a sua voz com a máscara da liberdade e da igualdade" (Hegel, 1999 [1837], p. 213). As repúblicas modernas só podiam ser uma democracia aparente, uma falsa igualdade e liberdade, trazendo o risco de um posterior estabelecimento de tiranias em nome dessas bandeiras.

Hegel retomou Montesquieu em seu argumento. "A virtude é a base da democracia, diz Montesquieu. Essa citação é tão importante quanto verdadeira no tocante à representação que normalmente é feita da democracia" (Hegel, 1999 [1837], p. 213). A virtude como 
sobreposição do bem comum só pode reinar no modo imediato, na consciência feliz da razão. Daí o absurdo de se pretender uma democracia na modernidade:

A vitalidade concreta nos gregos é a moralidade objetiva, a vida pela religião, pelo Estado, sem muitas reflexões, sem determinações universais que, ao mesmo tempo, se distanciem da deformação concreta e que precisem colocar-se perante ela. A lei existe e o espírito está nela. Todavia, logo que o pensamento surge, ele analisa as constituições: indica o que seria o melhor e exige que aquilo que ele reconheceu como o melhor substitua o existente. (Hegel, 1999 [1837], p. 227)

O problema com a tentativa de democracia na modernidade estaria justamente na impossibilidade do reino da virtude como abnegação, sacrifício. E tal seria inevitavelmente o caso da vida moderna. Nesta, não é a liberdade objetiva e sim a liberdade subjetiva que fundamenta o Estado. No caso dos gregos, o objetivo de vida pessoal era de fato a pátria, a comunidade. O Estado não era uma abstração (separação). Mas a virtude imediata, base para a democracia grega, já não seria possível num contexto de razão livre desenvolvida, de razão como subjetividade livre. Já que “o paraíso é um jardim onde só os animais podem permanecer, não os homens” (Hegel, 1999 [1837], p. 227), não era mais possível aos modernos a democracia: este era um Estado próprio da continuidade imediata homens-mundo perdida para sempre em sua forma ingênua com o desenvolvimento da consciência especulativa.

Foi o desenvolvimento da liberdade subjetiva que levou ao declínio da democracia na Grécia; na vida moderna é a liberdade subjetiva que reina: "Justamente a liberdade subjetiva, que determina o princípio e a forma característica da liberdade em nosso mundo - que é o fundamento do nosso Estado e da nossa vida religiosa -, significou para a Grécia a ruína" (Hegel, 1999 [1837], p. 213). Após o desenvolvimento da razão livre, portanto, o indivíduo nunca mais terá no Estado uma identidade completa, o Estado não poderá ser mais que uma unidade meramente formal entre interesse individual e coletivo. A unidade da liberdade subjetiva com a liberdade objetiva na modernidade só poderia ser real sendo formal. Perante essa constatação, o Estado próprio da razão madura seria uma unidade meramente formal - e não uma unidade concreta, tal como a Democracia. A razão moderna mais plenamente consciente seria assim uma forma voltada a si e, portanto, na modernidade o Estado em si só poderia ser Monarquia Constitucional.

\section{Filosofia dA HiSTÓRIA EM MARX: A (RE)CONCILIAÇÃo ENTRE A RAZÃo FILOSÓFICA E A DEMOCRACIA}

Nos Cadernos preparatórios de sua Tese de Doutorado intitulada Diferença entre as filosofias de Demócrito e Epicuro, Marx (1839) desenvolveu uma filosofia da história alternativa à de Hegel, indicando que a democracia não sofreu ocaso na Grécia por conta do desenvolvimento da razão filosófica, mas, sim, por conta da vitória da razão filosófica em que sofrera uma viragem para a teologia. Ou seja, diferente do que teria considerado Hegel, o Estado democrático 
não foi subsumido pela razão filosófica, e sim pela razão filosófica decaída. Marx buscou demonstrar ainda que foi justamente essa razão transformada em teologia que a modernidade herdou. O sistema epicurista - e não os alexandrinos - é que teria desenvolvido o dualismo de Anaxágoras de um modo verdadeiramente filosófico, de modo que a dissolução da democracia engendrada pelos alexandrinos e perpetuada na modernidade não teria sido um progresso da razão filosófica, e sim um retrocesso da consciência, uma espécie de viragem da filosofia em teologia. Assim, diferente do que teria considerado Hegel, o Estado democrático não era oposto ao caráter filosófico e à razão consciente, mas justamente o Estado da razão mais racional, da razão mais filosófica.

Retomando o mesmo ponto de partida de Hegel, Marx afirma que "o sábio, sophós, é obrigatoriamente concebido pela filosofia antiga de acordo com duas determinações que, embora diferentes, possuem ambas a mesma raiz. (...) A filosofia grega começa com sete sábios" (1972 [1839], p. 35). Entretanto, se concorda com Hegel que os sete sábios são a raiz da consciência filosófica, diferentemente deste ele mostra que os sete sábios iniciam a razão especulativa justamente por tomarem a verdadeira razão a partir de uma determinação popular objetiva. Assim, os sete sábios não são sábios por serem determinantes individuais da verdade, e sim por serem os primeiros a apreender que a vontade popular é que deve determinar a verdade. São, assim, sábios por partirem dos princípios objetivos da determinação da verdade e não de uma verdade fundada num mero idealismo:

Não se sacodem os poderes vivos: os filósofos mais idealistas desse período, os Pitagóricos e os Eleatas, glorificam a vida pública e fazem dela a verdadeira Razão. Os princípios desses filósofos são objetivos e constituem um poder que os invade a si próprios (...) se tornam eles próprios as imagens vivas, as obras de arte vivas que o povo vê sair de si mesmo na dimensão plástica (...) são a substância que possui o verdadeiro valor: as leis. (Marx, 1972 [1839], p. 37)

Para Marx, o poder dos sete sábios não teria emanado de uma iluminação individual e sim do povo. Os sábios pitagóricos e eleatas são a própria materialização daquilo que a vida pública glorifica. A razão não é individual, e sim popular. Apenas é plastificada em alguns indivíduos que então a transforma em leis. Ou seja, a razão sai do povo e não destes próprios indivíduos legisladores num desenvolvimento puramente conceitual, a perspectiva de plastificação indica uma corporificação no sentido de elaboração: a pessoa do legislador é formuladora das ideias do povo. Marx defende que os primeiros homens a serem tidos por sábios são justamente os bons leitores do clamor popular, de modo que a lei era respeitada não porque o povo glorificava invariavelmente os primeiros sábios, mas porque estes derivavam a verdade do povo e não de si mesmos, apenas elaboravam o saber manifestado pelo povo, não buscavam desenvolver verdades próprias na contramão dos desejos populares. Os legisladores que se tornaram os sete sábios foram justamente aqueles que entenderam que a razão não é um saber em si isolado do povo. A sabedoria dos sete sábios é assim uma razão que não se fechou em si, que não se isolou de sua determinação. Marx afirma que: 
A forma da vida dos pitagóricos é em si mesma a forma substancial, política, apenas tomada em abstrato e levada a um mínimo de extensão e de fundamentação natural (...) a forma na qual realizam o seu conhecimento da substância está a meia distância do isolamento total e consciente. (1972 [1839], p. 37)

O isolamento do sábio é parcial porque ser sábio não implica aqui ter o privilégio da verdade, e sim em ser especialmente capaz de apreender a vontade geral quando da elaboração das leis. O povo adora como sábios os legisladores que o compreendem verdadeiramente. O mesmo ocorreria em relação aos oráculos. Hegel teria dito que o povo não decidia nada por reflexão própria, por isso era comum que se recorresse aos oráculos, que seriam "uma subjetividade determinante da vontade" (Hegel, 1999 [1837], p. 191). Marx discorda disso considerando que o povo só adorou os oráculos do Apolo de Delfos quando estes expressaram a própria teoria do povo e, do mesmo modo, os sábios foram adorados apenas enquanto expressavam a própria sabedoria do povo:

Estes sábios são assim tão pouco populares como as estátuas dos deuses olímpicos. (...) Os oráculos de Apolo de Delfos não foram para o povo os representantes da vontade divina nem foram ornados pelo claro-escuro de um poder desconhecido senão enquanto o próprio poderio do espírito grego ecoou do alto do tripé pítico; o povo só se interessou teoricamente por eles enquanto foram a expressão da própria teoria do povo (...). O mesmo aconteceu com os sábios [primeiros legisladores]. Mas com os sofistas e Sócrates (na mesma linha da dýnamis ${ }^{3}$ que encontramos em Anaxágoras), a situação inverteu-se. (MARX, 1839, p. 37)

Assim, enquanto para Hegel o Estado só pode emanar do povo, ser democrático, quando o povo se identifica ingenuamente com as leis, Marx indica que o povo só se identifica com o Estado quando as leis, de fato, dele emanam. Além disso, também Marx considera que após Anaxágoras a situação começa a se inverter, mas não do mesmo modo que Hegel: a filosofia começa a sofrer com os alexandrinos uma viragem teológica justamente porque estes desenvolveram a razão como um voũs, seccionada do empirismo. Enquanto os pitagóricos são ainda sábios políticos, objetivos, legisladores e os eleatas ${ }^{4}$ já começam a se afastar um tanto do povo, em Anáxagoras a razão determinada passa a se supor pela primeira vez como uma

\footnotetext{
${ }^{3}$ Poderio. Tradução nossa.

${ }^{4}$ Marx (1972 [1839], p. 37) afirma que os eleatas (Zenão, Parmênides, dentre outros), os primeiros a idealizarem o mundo sensível, "a descobrir as formas ideais da substância”, teriam sido aqueles que "se afastam sem o desejar do povo e dos deuses antigos". A dúvida do mundo sensível e a busca de um ser imutável por trás das mutações constituídas por Parmênides na constante pergunta "o que é?” passam a desenvolver a primeira contraposição de fato ao mundo sensível como fundamento da razão e a buscar um em si uno e pressuposto ao mundo e suas transformações.
} 
inteligência autônoma, um voṽ ${ }^{5}$ constituidor do universo, uma pressuposição do mundo que é também determinante dele próprio.

Para Marx, o fato de o povo se voltar contra o voũ s de Anaxágoras demonstra como o caráter de sábio estava para os gregos completamente vinculado à razão como princípio objetivo. O povo rejeita Anaxágoras num protesto contra a forma de razão que se compreende como pressuposto de si mesma: "é o próprio povo que se afasta do antigo deus para se levantar contra o sábio individual” (Marx, 1972 [1839], p. 37). ${ }^{6}$ A rejeição do povo àquele que desenvolve uma razão autônoma é assim uma espécie de comprovação de que as leis não eram aceitas por advirem de uma divindade e os legisladores é que eram divinizados por atenderem ao clamor popular. O povo se contrapõe aos sábios tão logo estes deixam de ser receptáculos da vontade popular, de modo que a democracia não é uma razão mística superada pelo voũ $\varsigma$, este é que seria uma razão mística, alienada de sua determinação objetiva, que se opôs à verdadeira razão filosófica. É justamente porque os gregos democráticos não acreditam numa razão pressuposta que a vitória do voṽ c de Anaxágoras representa o início da derrocada do Estado democrático. Marx afirma que o dualismo de Anaxágoras é “o próprio elemento dualista que começa a cindir o coração mais íntimo do Estado” (Marx, 1972 [1839], p. 37).

Entretanto, Anaxágoras não foi exatamente promotor individual da absoluta viragem teológica, não foi exatamente um idealista unilateral, já que nem sempre usava a razão autônoma como fundamento explicativo. Na verdade, sua "idealidade da determinação real" (Marx, 1972 [1839], p. 37) só se fazia presente "perante as falhas de explicações físicas".7 Portanto, não se alienava sempre numa razão especulativa segregada, mas o fazia apenas quando não conseguia dar conta de explicar os fenômenos naturais a partir deles mesmos. Também o fato de ora explicar os fenômenos por uma razão em si, ora por investigações empíricas não teria feito dele o principal promotor do dualismo. Marx rejeita que o dualismo seja o desenvolvimento de uma razão puramente alienada, individual. Para ele, Anaxágoras apenas expressou os modos de razão desenvolvidos pelo conjunto objetivo da vida grega. Daí porque o dualismo permanece posteriormente na contraposição entre Sócrates e os sofistas:

Criticou-se recentemente o idealismo de Anaxágoras. (...) Mas, por um lado, essa aparência de dualismo não é mais do que o próprio elemento dualista que começa, na época de Anaxágoras, a cindir o coração mais íntimo do Estado; e, por outro, (...) só é empregado quando a determinação natural não existe. (...) Com isso, o voũ aparece como o núcleo da filosofia do filósofo errante e surge como todo o seu poder enquanto idealidade da determinação real, por um lado com os sofistas e por outro com Sócrates”. (Marx, 1972 [1839], p. 37)

\footnotetext{
${ }^{5}$ O termo voũ ć, muitas vezes, traduzido por "pensamento" e "inteligência" como sinônimos. Em Anaxágoras, trata-se da força motriz não material que constitui todo o mundo, dando-lhe ordem. ${ }^{6}$ Marx (1972 [1839], p. 37) refere-se ao fato de que, acusado de impiedade, Anaxágoras chegou a fugir de Atenas.

${ }^{7}$ Ibidem.
} 
Anaxágoras expressou o movimento objetivo de dualismo da razão filosófica e o que se contrapôs à democracia foi apenas a razão como idealismo unilateral, o que se demonstra pela falta de confiança do povo nesse tipo de racionalidade. Para Marx, Anaxágoras não foi tão completamente rejeitado quanto Sócrates, já que este vai desenvolver não exatamente o dualismo, tal como o fez Anaxágoras, mas apenas um dos lados deste dualismo: aquele da razão absolutamente determinante sobre si mesma a partir de si mesma, ou seja, a razão como determinação mais idealista.

Se em Anaxágoras o saber ainda é dado como determinado concretamente de algum modo, em Sócrates a substância racional passa a ser buscada como pressuposto único e absoluto. Mas quando a razão salta para fora da própria razão, ou seja, da sua própria determinação concreta, do povo, ela é estranhada. É por isso que Sócrates a trata como um daimónion interior:

O fato de esta idealidade da substância ter aparecido no espírito subjetivo e de ter saído da própria substância constitui um salto, uma queda para fora da vida substancial que tem suas condições no interior dessa vida. É por isso que esta determinação, que é a sua, é para o próprio sujeito um acontecimento, um poderio estranho de que ele é portador: o daimónion de Sócrates. (Marx, 1972 [1839], p. 39, grifos do autor)

Marx descreve que é por conta de um salto da razão determinada para fora da própria vida que a determina de fato, a democracia popular, para o interior da mera idealidade, que Sócrates não sabe de onde ela veio: a razão surge para ele como um espírito que se deu a si dentro de si. Sócrates não acompanhou o movimento de inversão dos sábios de receptáculos do povo para saber em si contraposto ao povo. Nele a razão é um salto para uma subjetividade em si, a razão autonomizada surge-lhe como algo estranho dentro dele, mas não por ele determinado. A razão se mistifica assim porque sua origem - rejeição do povo como verdadeiro legislador - não é apreendida, embora ainda se tenha consciência de que não se trata de uma determinação completamente solitária. Sócrates teria sido a expressão do contrassenso da filosofia em seu salto para fora de sua própria determinação. "Ela desempenha o papel de trampolim que, das representações e das diferenças substanciais etc., conduz à determinaçãoem-si” (Marx, 1972 [1839], p. 39). A razão estranhada é afirmada então como uma alma que se apoderou de sua pessoa, um daimónion. Se antes a razão deriva do povo, e os princípios dos filósofos são objetivos, agora "é a própria subjetividade que se dá como princípio da filosofia” (Marx, 1972 [1839], p. 39).

O fato de Sócrates ser ainda mais rejeitado pelo povo do que fora Anaxágoras é para Marx uma indicação de que nele a razão perdeu mais completamente seu aspecto objetivo, negou mais radicalmente um de seus modos de determinação efetiva e, por isso, foi rejeitada. A democracia revela-se assim uma razão mais filosófica: não está de acordo com uma razão inconsciente de sua própria determinação, ou seja, se opõe a uma razão inconsciente de sua determinação objetiva. Como Anaxágoras, Sócrates é fruto de seu tempo: ele também expressa um estranhamento da razão em relação à sua própria determinação e a simultânea 
consciência dos gregos de que não se trata de uma determinação puramente individual do sábio. "O daimónion é a manifestação imediata do fato de a filosofia ser para a vida grega tanto algo puramente interior como puramente exterior" (Marx, 1972 [1839], p. 39).

A condenação de Sócrates expressa o modo como a democracia se opõe à determinação unilateral da razão. Trata-se da condenação da razão como ser em si: Sócrates é condenado justamente porque a razão não é meramente subjetiva, mas fruto da determinação popular. Assim, a morte de Sócrates é uma consequência não de sua razão ser mais consciente de seus princípios, e sim de ser uma razão confusa. Sócrates é condenado não porque desenvolve uma razão mais filosófica, mas por desenvolver uma razão mais idealista, uma razão que ainda não aprendeu a suportar as contradições:

[Sócrates] é ele próprio dividido e condenado, pois a sua raiz é em parte o substancial e o direito da sua existência encontra-se no direito do seu Estado, da sua religião, enfim, de todas as condições substanciais que surgem nele como sua natureza. Então a sua própria substancialidade está assim condenada nele; e ele desaparece justamente porque o lugar do seu nascimento é o espírito substancial e não o espírito livre que suporta todas as contradições e as vence. (Marx, 1972 [1839], p. 39)

Marx retoma Hegel em sua afirmação do espírito livre como aquele que abraça a contraditoriedade ao invés de negá-la, mas o faz para afirmar a negação da democracia como a negação unilateral da contraditoriedade e, portanto, como um retrocesso da razão filosófica. Para Marx, a importância de Sócrates é que ele teria sido a expressão mais evidente de que, ao fechar-se em si mesma, a razão especulativa perde seu caráter filosófico, sua possibilidade de vencer positivamente a contraditoriedade. E a importância da oposição da democracia à Sócrates é o modo como a democracia se mostra uma razão que rejeita a razão incapaz de suportar a contradição. Em Sócrates a filosofia mostrou seu limite interno na tentativa de ser pressuposto de si mesma. Marx indica que foi exatamente contra este limite da razão especulativa fechada que a democracia se voltou: "Se Sócrates tem uma tal importância é apenas porque nele surge a relação da filosofia grega com o espírito grego e, portanto, o limite interno dessa filosofia" (Marx, 1972 [1839], p. 39). Ao condenar à morte a razão que se pretende deduzida da mera subjetividade, a democracia teria se revelado uma razão oposta à unilateralidade e, portanto, filosófica. Ocorre que a democracia é vencida pela razão idealista. Marx indica que, se em Sócrates a pretensão de a razão ser autonôma ainda não chegara a se impor, já que na sua condenação ainda há uma dialética - a ideia "volta-se para o exterior, contra a realidade, é praticamente imiscuída nesta e a sua existência torna-se o movimento"

\footnotetext{
${ }^{8}$ Marx explica que no momento socrático a razão é ainda interior ao ser concreto, ao corpo do filósofo, na medida em que Sócrates se julga portador de um poder estranho não como um deus, e sim como um homem real. Ao mesmo tempo em que não trata o saber como uma determinação da vida popular, Sócrates ainda a considera fruto de determinação objetiva no sentido individual, ou
} 
(Marx, 1972 [1839], p. 38) -, Platão expressa a razão mais completamente autonomizada. E é esta razão mais fechada que se mantém na modernidade após a derrocada da democracia.

Para Marx, Platão desenvolve uma autonomização ainda mais completa da razão do que Sócrates, já que nele a idealidade é uma totalidade em si fora de qualquer determinação objetiva individual: o saber deixa de ter qualquer indução particular e passa a ser como um bem em si que surge a partir de si mesmo de modo totalmente anterior à particularidade concreta: "em Platão, esta determinação do bem, do objetivo, dá origem a uma filosofia extensiva que envolve o mundo" (Marx, 1972 [1839], p. 41). Da contraposição ao mundo, a razão desenvolve-se como um mundo à parte. Em Platão, a razão em si é o mundo total; a totalidade é uma Ideia em si que envolve o mundo. Nele, portanto, a subjetividade do filósofo aliena-se também do próprio sujeito filósofo e se antepõe mais completamente à sua determinação objetiva, surgindo não como antítese da razão do filósofo à razão dada na democracia determinada, mas como uma essência, verdade e realidade total em si mesma. Daí porque Platão fala de um mundo ideal como o mundo real a partir do qual a realidade é uma ilusão: as ideias reais pairam sobre essa ilusão e nelas está o devir desta falsa realidade em verdade.

Marx afirma que em Platão a idealidade fecha-se numa autonomia total e o surgimento da razão fundamentalmente cindida do mundo plural se efetiva. A despeito do que poderia expressar a condenação de seu mestre, Platão desenvolve o princípio socrático numa determinação completamente abstrata do bem, numa filosofia radicalmente fechada em si: "É esta a concepção que Platão tem das suas relações com a realidade efetiva: um reino das ideias independente paira acima da realidade e reflete-se obscuro nela" (Marx, 1972 [1839], p. 39). Na verdade, entretanto, Platão estaria enganado: o seu mundo ideal seria determinado pelo mundo objetivo e não o contrário. Para demonstrar isso, Marx recorre a Aristóteles:

Aristóteles faz uma observação bastante justa: 'Pois as formas são quase semelhantes e quase tão numerosas como as coisas de que partem estes pensadores, à procura das suas origens, para atingir as formas (...) mesmo que houvesse formas não seria por isso que poderia nascer qualquer coisa que delas fizesse parte, a menos que não exista mais nada que dê origem ao movimento' [Aristóteles]. (Marx, 1972 [1839], p. 39)

Portanto, Platão desenvolve contra a democracia grega que condenou Sócrates não o aspecto filosófico da razão filosófica, e sim a idealidade unilateral. Nele, o sábio é apenas um filósofo enquanto tal. Não é o filósofo como receptáculo do povo - verdadeiro espírito geral -, e sim enquanto receptáculo de um bem em si conceitual, de um bem além, acima da vontade popular. Platão revelara de modo explícito que, ao contrário do que consideraria Hegel posteriormente, é a especulação meramente idealista, e não a filosofia dialética, que se contrapusera à democracia:

seja, o saber ainda deriva de certo modo da realidade efetiva, ainda que nos limites de sua própria individualidade, o que já não ocorrerá em Platão. 
O filósofo enquanto tal, isto é, enquanto é sábio e não o movimento do espírito verdadeiro em geral, constitui assim a verdade transcendente do mundo substancial que se encontra perante si mesmo. Platão revela-o da maneira mais clara quando afirma que seria necessário que os filósofos se tornassem reis ou que os reis se tornassem filósofos para que o Estado atingisse a sua determinação. Aliás, ele próprio fez essa tentativa dado que se encontrava à mercê de um tirano. (Marx, 1972 [1839], p. 39)

Marx não recusa que exista um movimento do espírito verdadeiro em geral, mas busca mostrar que este não principia na razão como autonomia em si mesma, que ele não é uma determinação em si. A dialética da razão, movimento do espírito em geral, não é completamente transcendente do mundo objetivo, antes é o próprio filósofo que transcende e justamente quando se dá como sábio numa contraposição hierárquica aos homens comuns. Em Platão, o filósofo não é sábio porque determinado objetivamente pelo povo (tal como no caso dos sete sábios), mas sábio enquanto tal, daí porque só seria verdadeiramente racional o Estado governado por filósofos. Para Marx, em sua queda no idealismo, Platão paralisou o movimento do pensamento filosófico, do pensamento como diálogo do idealismo com o campo objetivo. Assim, de fato os primeiros sábios foram o início do movimento da razão filosófica, mas com os alexandrinos esta sofreu um desvio. Há no início o movimento propriamente filosófico da razão, mas "o movimento em Platão torna-se movimento ideal" (Marx, 1972 [1839], p. 41) e se paralisa: "Platão quer transferir para a idealidade não apenas alguns seres, mas toda a esfera do ser: esta idealidade é um reino fechado, diferenciado especificamente na própria cabeça filosofante; e precisamente porque o é; falta-lhe o movimento" (Marx, 1972 [1839], p. 43).

Portanto, ao contrário do que considerou Hegel, Platão não marca a continuidade do desenvolvimento da razão num sentido mais filosófico, e sim de uma razão filosófica que sofrera uma viragem para a teologia. Marx concorda com Hegel que o sistema alexandrino de fato negou a democracia, mas discorda que tal sistema tenha representado um momento positivo no desenvolvimento da razão filosófica. O sistema alexandrino teria sido, na verdade, um desvio da razão filosófica de seu caminho mais filosófico no momento em que se fechara numa especulação puramente conceitual. Assim, a democracia - e não a sua dissolução - é que teria sido o momento de aprimoramento da razão filosófica. Neste sentido, Marx busca então retomar como mais filosófica a filosofia dialética que escapou do desvio promovido pelos alexandrinos: o epicurismo.

O próprio Hegel destacara Epicuro dentre os filósofos ecléticos à filosofia alexandrina - "o grego Anaxágoras foi o primeiro a afirmar que o voũ - a inteligência em geral ou razão - rege o mundo (...) Sócrates adotou o pensamento de Anaxágoras, que se tornou dominante na filosofia - com exceção de Epicuro, que atribuía todos os acontecimentos ao acaso" (Hegel, 1999 [1837], p. 19) - entretanto, não apreendera que Epicuro representara o ocaso positivo da filosofia grega. Marx busca retomar o atomismo de Epicuro no sentido de demonstrar que tal sistema é mais filosófico do que o alexandrino e de pontuar alguns 
elementos importantes para que o desenvolvimento da filosofia siga no seu rumo mais filosófico também na modernidade, no rumo de uma razão democrática.

O elogio ao sistema de Epicuro promovido por Marx remete à busca de uma saída do idealismo hegeliano, mantendo-se numa filosofia dialética. Marx afirma que os filósofos partem tradicionalmente de pressupostos da consciência e acabam por buscar como base substancial a representação comum - "todos os filósofos antigos, incluindo os céticos, partem de pressupostos da consciência, torna-se necessária uma base sólida que é fornecida pelas representações que se encontram na consciência comum” (Marx, 1972 [1839], p. 11) - e que Epicuro, embora seja também um filósofo da representação, nega simultaneamente a representação como um espelho do mundo em si, afirmando-a como mera projeção da criação ideal sobre o mundo. Epicuro teria sido um filósofo da representação mais rigoroso. ${ }^{9}$ $\mathrm{O}$ avanço fundamental de Epicuro teria sido reconhecer o seu conceito de causa única como mera ilusão, de modo que seu pressuposto acaba por suprimir-se:

[Em Epicuro] vimos que os átomos, considerados abstratamente, não são mais do que seres representados como existindo e que apenas sua colisão com o concreto permite desenvolver a sua idealidade fictícia e por isso mesmo envolvida em contradições. Demonstram igualmente, ao constituírem um dos lados da relação (quando se consideram objetos que tem em si mesmos o princípio e o seu mundo concreto - o vivo, o animado, o orgânico) que o reino da representação é pensado ou como sendo livre ou como constituindo o fenômeno de uma coisa ideal. (Marx, 1972 [1839], p. 11)

Se o mérito de Epicuro é subsumir o conceito-causa, é no modo como ele define o átomo que está a sua negação da existência de um princípio em si do mundo. Isso porque, para ele, o átomo seria apenas a representação de um limite para o mundo sensível criado pela consciência filosofante que questiona a verdade dos fenômenos. Ao dar o átomo como uma idealidade de princípio em si, Epicuro negara tal princípio como existente no mundo e admitira-o como fictício. O átomo seria mera subjetividade humana que se pensa livre e dá a si como totalidade absoluta indeterminada sem, de fato, o ser. A subjetividade não é absolutamente livre: "Esta liberdade da representação é então uma liberdade apenas pensada, imediata, fictícia, ou seja, o atomismo na sua forma verdadeira" (Marx, 1972 [1839], p. 14). O átomo (princípio em si) é uma ficção porque é mera idealidade e porque a liberdade da idealidade em si é pura ficção.

Epicuro promoveu assim um deslocamento da questão tradicional da filosofia: de como o mundo múltiplo surgiu de um princípio em si para como a representação de princípio em si surgiu. E sua resposta a essa última prosseguiu sua originalidade: as representações do mundo são dadas como criações livres e casuais da consciência em seu confronto com o mundo. O problema é que foi justamente a filosofia alexandrina que continuou viva na modernidade:

\footnotetext{
9 "Epicuro, enquanto filósofo da representação, mostra-se neste ponto mais rigoroso do que qualquer outro e define melhor as condições desse fundamento” (Marx, 1972 [1839], p. 11).
} 
A figura que vemos sair do laboratório da consciência Grecofilosófica, da obscuridade da abstração, coberta com suas vestes sombrias, é a figura com a qual a filosofia grega caminha viva pela cena do mundo (...) a mesma figura bebeu a taça de veneno, a mesma que, depois de se tornar o deus ${ }^{10}$ de Aristóteles, gozou da maior felicidade na Teoria (contemplação). (Marx, 1972 [1839], p. 160)

Marx concorda aqui com Hegel que é a filosofia alexandrina que se manteve viva na filosofia moderna e que houve o desenvolvimento de uma liberdade subjetiva ainda mais radical na modernidade. Entretanto, para ele, o não reconhecimento desta liberdade subjetiva como um idealismo fictício é o núcleo íntimo dessa desgraça moderna: "O núcleo íntimo da desgraça é constituído pelo fato de a alma dessa época, a mônada espiritual que se basta a si mesma e é em si mesma representada idealmente de todos os pontos de vista, não reconhecer nenhuma realidade que exista sem a sua intervenção" (Marx, 1972 [1839], p. 88). Hegel não entrevera que, ao tentar desenvolver-se como livre, a razão filosófica caiu numa existência ontológica independente (teologia) e paralisou seu desenvolvimento dialético.

Ao remeter a crítica a Hegel num contexto em que afirma uma tendência de misticismo presente na própria natureza da filosofia alexandrina a que este dera continuidade, tal crítica de Marx pretende-se, ao mesmo tempo, uma salvaguarda da dialética hegeliana: ele não tinha consciência de que partia de um princípio revirado num idealismo unilateral, tal como o era a filosofia alexandrina. Para Marx, a viragem mística de Hegel não seria culpa deste. O risco de viragem da filosofia em teologia encontrava-se não só em Hegel, mas em toda tentativa da razão de se impor sobre o mundo:

Que um filósofo cometa uma inconsequência por comodismo é compreensível, até pode ter consciência disso. Mas aquilo de que não pode ter consciência é que a possibilidade de uma tal adaptação aparente tem sua origem mais profunda numa insuficiência ou numa compreensão insuficiente do princípio de que parte. Se tal acontecer a um filósofo, os seus discípulos devem explicar a partir da consciência intima e essencial desse filósofo o que nele apresentava a forma de uma consciência exotérica. Desse modo, o que constitui um progresso da consciência é simultaneamente um progresso da ciência. Não se suspeita da consciência particular do filósofo; descobre-se a forma essencial dessa consciência, atribui-se-lhe uma caracterização e um significado determinados e, desse modo, ela é ultrapassada. Aliás, considero esta viragem para a não-filosofia manifestada por grande parte da escola hegeliana como um fenômeno que acompanhará sempre a passagem da disciplina para a liberdade. (Marx, 1972 [1839], p. 57)

\footnotetext{
${ }^{10}$ Aristóteles se contrapôs ao antropomorfismo afirmando deus como uma autoconsciência que se limita a contemplar a essência das coisas, que nada mais são que sua própria essência.
} 
Marx considera que não se podia simplesmente invalidar o sistema filosófico que sofreu uma viragem para a teologia, não se podia simplesmente invalidar o sistema de Hegel. Pois, se é verdade que a filosofia de Hegel caíra num puro idealismo tal como os sistemas anteriores, era preciso avaliar que havia um problema comum com os pressupostos dos filósofos modernos, com a forma essencial dessa consciência idealista. Hegel compreendeu seus pressupostos na filosofia moderna e alexandrina, mas de modo insuficiente, e que a insuficiência de um pensador a respeito de seu próprio sistema é mais compreensível do que a dos filósofos posteriores em relação a ele. Estes precisam tomar consciência da insuficiência do princípio da filosofia anterior, daquilo que fez com que esta assumisse uma forma exotérica. Caberia aos herdeiros do sistema de Hegel não simplesmente rejeitá-lo, mas identificar os problemas nos pressupostos de tal sistema; problemas de que o próprio filósofo não podia ter consciência.

\section{REFERÊNCIAS}

DUMÉNIL, Gérard; LÖWY, Michael; RENAULT, Emmanuel. Ler Marx. Trad. Mariana Echalar. São Paulo: Unesp, 2011.

FAUSTO, Ruy. Marx: lógica política. Investigações para uma reconstituição do sentido da dialética. Tomo I. 2 ed. São Paulo: Brasiliense, 1987.

FREDERICO, Celso. O jovem Marx (1843-1844): as origens da ontologia do ser social. São Paulo: Expressão Popular, 2009.

HEGEL, Georg Wilhelm Friedrich. Filosafia da história. Trad. Maria Rodrigues e Hans Harden. 2 ed. Brasília: Ed.UnB, 1999.

KORSCH, Karl. Marxismo e filosofia. Rio de Janeiro: Ed.UFRJ, 2008.

LÖWITH, Karl. From Hegel to Nietzsche: the revolution in nineteenth-century thought. Translated from German by David E. Green. New York: Columbia University Press, 1964.

LÖWY, Michael. A teoria da revolução no jovem Marx. Trad. Anderson Gonçalves. Petrópolis, Rio de Janeiro: Vozes, 2002.

LUKÁCS, Georg. O jovem Marx e outros escritos de filosofia. Org. e trad. Carlos Nelson Coutinho e José Paulo Netto. Rio de Janeiro: Ed. UFRJ, 2009.

MARX, Karl. Diferença entre as filosofias da natureza em Demócrito e Epicuro. Trad. Conceição Jardim e Eduardo Lúcio Nogueira. Lisboa: Presença, 1972.

MARX, Karl. Crítica da filosofia do direito de Hegel. Trad. Conceição Jardim e Eduardo Lúcio Nogueira. Lisboa: Presença, 1983.

MARX, Karl; ENGELS, Friedrich. Collected Works (MECW). New York: International Publishers, 1975. 50 v. Disponível em: <http://www.marxists.org/archive/marx/works/ $\mathrm{cw} /$ index.htm>. 
MARX, Karl; ENGELS, Friedrich. Luta de classes na Alemanha. Apresentação Michael Löwy. Trad. Nélio Schneider. São Paulo: Boitempo, 2010.

McLELLAN, David. Karl Marx: his life and thought. Norwalk: The Easton Press, 1990.

MÉSZÁROS, István. A teoria da alienação em Marx. Trad. Isa Tavares. São Paulo: Boitempo, 2006.

SAMPAIO, Benedicto Arthur; FREDERICO, Celso. Dialética e materialismo: Marx entre Hegel e Feuerbach. Rio de Janeiro: Ed. UFRJ, 2006.

SILVA, Romero Junior Venâncio. "O Epicuro de Marx: algumas notas". Prometeus, ano 4, n. 8, julho-dezembro, 2011.

TEXIER, Jacques. Revolução e democracia em Marx e Engels. Trad. Duarte Pacheco Pereira. Rio de Janeiro: Ed. UFRJ, 2005.

Recebido em 4 de setembro de 2016 Aprovado em 9 de maio de 2017 